\title{
Seroprevalence of Japanese enchephalitis Infection in Pigs in Tulungagung, East Java
}

\section{Seroprevalensi Infeksi Japanese Enchephalitis pada Babi di Tulungagung, Jawa Timur}

\author{
Dyah Widiastuti ${ }^{1 *}$, Tri Wijayanti ${ }^{1}$, Tri Isnani ${ }^{1}$, Nova Pramestuti ${ }^{1}$, Siwi Mars Pramatama Wijayanti ${ }^{2}$ \\ ${ }^{1}$ Balai Penelitian dan Pengembangan Kesehatan Banjarnegara \\ Jalan Selamanik No 16 A Banjarnegara, Jawa Tengah, Indonesia \\ ${ }^{2}$ Jurusan Kesehatan Masyarakat, Fakultas Ilmu-Ilmu Kesehatan, Universitas Jenderal Soedirman \\ Jalan Dr. Soeparno Karangwangkal, Purwokerto Utara, Jawa Tengah, Indonesia \\ E_mail: umi.azki@gmail.com
}

Received date: 12-06-2019, Revised date: 24-09-2019, Accepted date: 11-10-2019

\begin{abstract}
ABSTRAK
Babi memainkan peran sebagai amplifying host untuk Japanese enchephalitis (JE), sehingga surveilans infeksi JEV pada babi sangat penting dilakukan untuk mencegah tranmisi virus ini ke manusia. Penelitian ini bertujuan untuk mengetahui tingkat infeksi JE pada babi sebagai penilaian risiko JE pada manusia. Daerah penelitian terletak di Kabupaten Tulungagung, salah satu kabupaten di Provinsi Jawa Timur dengan jumlah peternakan babi terbanyak. Penelitian ini menggunakan rancangan cross sectional, dilakukan di 5 peternakan babi di Kabupaten Tulungagung pada bulan April-November 2016, dengan total 63 ekor babi yang diperiksa. Darah vena diambil dari masing-masing babi dan diperiksa menggunakan IgG-Enzyme Link Immuno-Sorbent Assay (IgG-ELISA) spesifik JEV. Hasil penelitian menunjukkan bahwa tingkat infeksi JE pada sampel babi secara keseluruhan adalah 19,05\% (12/63). Prevalensi Ab JE pada babi usia 4-6 bulan lebih tinggi (22,7\%) dibandingkan dengan babi usia 2-3 bulan. Infeksi JE pada babi cenderung lebih tinggi (23,1\%) pada peternakan yang ditemukan positif jentik Culex. Jenis kelamin, umur babi dan keberadaan jentik Culex di sekitar peternakan babi tidak berhubungan secara signifikan dengan besarnya angka infeksi JE pada babi. Keberadaan antibodi virus JE pada populasi babi di Tulungagung menunjukkan ada potensi transmisi virus JE pada manusia.
\end{abstract}

Kata kunci: Japanese encephalitis, babi, seroprevalensi

\begin{abstract}
Pigs play a role as amplifier hosts for Japanese enchephalitis (JE). Surveillance of JEV infection on pigs, is, therefore undoubtedly important to prevent its transmission to humans. This study aims to investigate the infection rates of JE in pigs as a risk of JE in human. The study area was located in Tulungagung regency, one of the regencies in East Java with the largest number of pig farms. This was a cross sectional study, involving five pig farms in Tulungagung Regency during April-November 2016, with a total of 63 pigs examined. Venous blood was examined by JEV specific IgG-Enzyme Link Immuno-Sorbent Assay (ELISA). The results showed that the JE infection rates in overall pig samples was $19.05 \%(12 / 63)$. The prevalence of Ab JE in 4-6 month pigs is higher $(22.7 \%)$ than in 2-3 month pigs. The infections in pigs tend to be higher $(23.1 \%)$ in farms found to be positive for Culex larvae. Sex and age of the pig and the presence of Culex larvae surround pig farms were not significantly associated with JE infection rates in pigs. In conclusion, the presence of JE virus antibodies in pigs population in Tulungagung indicates that there is a potency of JE virus transmission to humans.
\end{abstract}

Keywords: Japanese encephalitis, pig, seroprevalence

\section{INTRODUCTION}

Japanese encephalitis (JE) virus is one of the arbovirus that causes health problems in the world, including Indonesia. This virus is considered as a major cause of encephalitis in Asia, mainly in rural and suburban areas where rice culture and pig farming coexist. ${ }^{1}$
Twenty-four countries in the WHO South-East Asia and Western Pacific regions experienced endemic JEV transmission, with more than 3 billion people at risks of infection. Globally, it estimated around 68000 clinical cases of JE each year, with approximately 13600 to 20400 deaths. $^{2}$ 
This disease is mostly asymptomatic, except in pregnant cows may result in a miscarriage or a piglet will be stillborn. ${ }^{2}$ Japanese encephalitis virus is included in the JEV serogroup of the genus Flavivirus, Flaviviridae family. The virus has singlestranded RNA with positive-sense in round direction, with $11 \mathrm{~kb}$ genome. Its virion contains seven non-structural proteins NS1, NS2A, NS2B, NS3, NS4A, NS4B, and NS5 as well as three structural proteins consisting of nucleocapsid or core protein (C), nonglycosylated membrane protein $(\mathrm{M})$, and glycosylated envelope protein (E). ${ }^{3}$ Japanese Encephalitis Virus is transmitted principally by the vector mosquito Culex tritaeniorhynchus, and is maintained through zoonotic cycles between pigs and swamps, with humans as incidental dead-end hosts. This mosquito species has been reported to prove positive for JE virus in Surabaya. ${ }^{4}$ The mosquito breeding place is commonly in irrigated rice fields, and therefore this disease mainly occurs in rural areas. ${ }^{1,5}$

Pigs play a role as amplifying hosts, and a high density of pigs can be associated with increased number of cases of JE in certain area. It is believed that there are two prerequisites for JEV transmission, the presense of competent vectors and pigs as the main amplifying host. The close proximity of pigs to human settlements could increase the risks for JEV transmission to human. ${ }^{6}$ The JE infection in Indonesia was confirmed from female $C x$. tritaeniorhynchus mosquitoes collected at the area where suspected JE cases found in Sidotopo Wetan, Kenjeran Subdistrict and Kedurus Village, Karang Pilang District, Surabaya. $^{5}$ In 2014, sub-sequent JE surveillance activities were conducted in 11 sentinel sites recognized as JE endemic areas. Routine surveillance was conducted by collecting sera from suspected human JE cases. A total of 8 and $40 \mathrm{JE}$ cases were confirmed in 2014 and 2015, respectively. In 2016, surveillance activities were continued in 11 provinces and a total 43 out of 326 human serum samples from individuals with JE symptoms were confirmed positive by IgM ELISA. ${ }^{7}$ Clinical manifestations of JEV infection in human are mostly asymptomatic, only small proportion develop into brain inflammation. The major clinical symptoms present in JE patients are fever, decrease in consciousness, mental status changes, paralysis, and convulsions. ${ }^{8}$

The potential of transmission from pigs to humans makes JE surveillance in pigs undoubtedly important. Positive pigs containing JE specific $\mathrm{Ab}$ were reported in several previous research in several areas in Indonesia, namely $53.6 \%$ in Jakarta, West Java, and Central Java 88-97\% , Bali 64-80\%, East Java 6\%, ${ }^{9}$ Riau $94 \%$ and North Sumatra $70 \%$. In Surabaya, the JE specific antibody is found in several animal species including orangutans, cattle, pigs and goats, with the highest rates of infection in pigs. ${ }^{8}$ Confirmation of JE cases was conducted in East Java Province, especially in Jombang District where there were 8 cases of $\mathrm{JE}$ in humans in 2005-2006. Tulungagung regency is one of the districts in East Java province with the largest number of pig farms. Pigs in Tulungagung increased from 2,972 in 2010 (19.03\% of pig population in East Java Province) to 10,058 in $2013(21.82 \%)$ and increased to $10,567(25.23 \%)$ in 2014. ${ }^{9}$ Yamanaka et $a .^{10}$ reported that JE-specific antibodies in pigs were found in Tulungagung District by $6 \%$ (96 pigs) based on hemagglutination-inhibition (HAI) test. Antibodies against JE virus were also found in $53 \%(\mathrm{n}=28 / 52)$ blood samples from the pigs in East Sumba and 49\% ( $n=60 / 123)$ in Bali. ${ }^{10,11}$ In addition to pigs, there is growing evidence that other vertebrates may have a similar role in JE transmission in certain areas in Indonesia. This is also important to consider for understanding JEV transmission ecology. Ducks and chickens were shown likely to produce a JEV viremia sufficient to infect mosquitoes. ${ }^{6,12,13}$

Previous studies showed that pigs can act as the main reservoir of JE virus in Indonesia, therefore investigation of JEV 
infection on pigs is indeed important to be carried out. This study aims to investigate the infection rates of $\mathrm{JE}$ in pigs as the main reservoir in order to assess the risk of JE in human. Pigs are the main amplifying host and due to this fact, pig husbandry may increase the risk of human JEV transmission as pigs are often kept in close proximity to households. The understanding of JE infection in pigs can serve as an indicator of the possibility of the threat of JE transmission to humans, especially if the location of pig farms close to the settlement.

\section{METHODS}

This study was a cross sectional survey conducted in two sub-districts in Tulungagung regency, namely Ngunut and Kalidawir, during April-November 2016. Those areas have pig farms in Tulungagung Regency. Pigs were grouped into two categories, one from 2 to 3 month and another from 4 to 6 month of age. A total of 67 pigs was examined from the five farms in the area of study. The sample selection carried out purposively in accordance with the permit obtained from the owner of the farm. In addition to surveying pigs, a survey of mosquitoes and breeding sites was carried out in the research activities, both in pig farms and around pig farms (houses of residents, around cages of cattle and chickens).

At least $5 \mathrm{ml}$ of venous blood was taken from auricularis externa vein in large pigs or saphenous vein in small pigs. Pigs are not sedated at the time of bleeding. Each sample of pigs was recorded on the characteristics of pigs (age and sex). Blood specimens were stored in an upright position in the refrigerator at $2-8^{0} \mathrm{C}$ for one night in order for the serum to separate from the blood cells. The following day, the serum was taken with pipette and then inserted into a separate microsentrifuge tube. Then serum samples were transferred to Laboratory of Microbiology, Molecular Biology and Immunology of $\mathrm{R} \& \mathrm{D}$ Center, P2B2 Banjarnegara. During transport to the laboratory, serum samples were stored in ice box at temperature of $2-8{ }^{\circ} \mathrm{C}$. Once arrived in laboratory, serum samples were transferred to a frozen cabinet at $-20{ }^{\circ} \mathrm{C}$ in the laboratory until examined.Serum tests were subjected to ELISA, a standard examination technique for JE according to WHO guidance. ${ }^{14}$ Pigs were categorized as infective with JE if the results showed positive JE antibody.

Data were analyzed descriptively to determine the magnitude of JE infection rates and categorized by region and pig characteristics (age and sex) and the presence of Culex larvae surround pig farms (less than $50 \mathrm{~m}$ from the cage). Larvae that were found in study area were kept in the laboratory to identify the species. Bivariate analysis with chi square test (CI 95\%) was carried out to assess the relationship between sex of pig and the presence of Culex larvae surround pig farms with infection of JE. Spearman correlation test was used to determine whether there was relationship between age of pig with JE infection.

This research has received approval from the Ethics Committee of the Agency for Research and Development of Health, Ministry of Health of Indonesia (No approval: LB.02.01/5.2/KE.159 /2016, dated 4 April 2016). Blood collection on pig was conducted after permission from the owners of pig farms.

\section{RESULTS}

In this study, 63 of pigs from five pig farms were examined, most of which came from Ngunut subdistrict. Based on the result, the prevalence of pigs containing specific JE antibody in the area of study is $17.9 \%$ (Table $1)$. 
Table 1. Number of Pigs Examined and Positive JE Antibodies at Each Farm in Tulungagung District

\begin{tabular}{ccccc}
\hline Sub district & Farms & $\begin{array}{c}\text { Number of pigs } \\
\text { examined }\end{array}$ & $\begin{array}{c}\text { Number of pigs with } \\
\text { positive Ab JE }\end{array}$ & Percentage (\%) \\
\hline Ngunut & Farm A & 14 & 3 & 21.4 \\
& Farm B & 12 & 3 & 25.0 \\
& Farm C & 13 & 3 & 23.1 \\
& Farm D & 11 & 2 & 18.2 \\
Kalidawir & Farm E & 13 & 1 & 7.7 \\
\hline Total & & 63 & 12 & 19.05 \\
\hline
\end{tabular}

The prevalence of positive JE antibody on female pigs is slightly more than on male group. Based on the age of pigs, the prevalence of positive JE antibody in 4-6 months pigs are higher $(22.7 \%)$ than in $2-3$ month pigs.
Nevertheless, statistical test results showed no association between sex, age of pigs and the existence of Culex larvae surrounding pig farms with JE infection in pigs (Table 2).

Table 2. Number of Pigs Examined and Positive JE Antibodies in Tulungagung District by Age and Sex

\begin{tabular}{|c|c|c|c|c|c|c|}
\hline \multirow[b]{2}{*}{ Pigs characteristic } & \multirow{2}{*}{$\begin{array}{l}\text { Number of } \\
\text { pigs } \\
\text { examined }\end{array}$} & \multicolumn{2}{|c|}{ Positive Ab JE } & \multicolumn{2}{|c|}{ Negatif Ab JE } & \multirow[b]{2}{*}{$p$-value } \\
\hline & & total & $\%$ & total & $\%$ & \\
\hline Age (months) & & & & & & 0.341 \\
\hline$-2-3$ & 41 & 7 & 17.1 & 34 & 82.9 & \\
\hline$-4-6$ & 22 & 5 & 22.7 & 17 & 41.5 & \\
\hline Sex & & & & & & 1.000 \\
\hline - Male & 26 & 5 & 19.2 & 21 & 80.7 & \\
\hline - Female & 37 & 7 & 18.9 & 30 & 81.1 & \\
\hline $\begin{array}{l}\text { Existance of Culex } \\
\text { larvae arround the pig } \\
\text { farms }\end{array}$ & & & & & & 0.700 \\
\hline - Presence & 13 & 3 & 23.1 & 10 & 76.9 & \\
\hline - Absence & 50 & 9 & 18 & 41 & 82 & \\
\hline
\end{tabular}

Tabel 3. The Presence of Culex Breeding Site Inside and Arround the Pig Farms

\begin{tabular}{lccc}
\hline \multicolumn{1}{c}{ Pig Farms } & $\begin{array}{c}\text { Presence of Culex } \\
\text { larvae }\end{array}$ & Inside pig farms & Type of breeding sites \\
\hline Pig Farm A & Negative & - & Arround pig farms \\
Pig Farm B & Negative & - & - \\
Pig Farm C & Positive (Culex sp.) & Water reservoir & $\begin{array}{c}\text { Puddle of household waste water, } \\
\text { water reservoir in chicken farm, } \\
\end{array}$ \\
& & & puddle of waste water from cattle \\
Nig Farm D & Negative & - & pens \\
Pig Farm E & Negative & - & - \\
\hline
\end{tabular}

Table 3 showed that Culex larva only found around one pig farm (pig farm C), both inside and around pig farm. The distance of the Culex larva breeding found around the pig farm is $50-250$ meters from the Ab JE positive pig farm. JE infections in pigs tend to be higher $(23.1 \%)$ in farms found to be positive for Culex larvae. However, the results of the fisher exact test showed that the presence of Culex larvae around pig farms was not significantly associated with JE infection in pigs. 


\section{DISCUSSION}

Pigs as amplifying hosts for JE viruses play important role for disease tranmission, despite this virus will replicate without causing clinical symptoms in pigs. During the course of viremia, pigs can be bitten by $C x$. tritaeniorhynchus mosquitoes, which in turn, passes the virus to other pigs or to humans as dead end host. ${ }^{5}$ The results of this study indicated that pigs with positive JE antibody were found in all five farms in the area of study. Positive female pigs is slightly more than the male. and pigs of 4-6 months are higher $(22.7 \%)$ than of 2-3 month. The prevalence of positive pigs in this study had slightly higher than thatconducted by Ompusungu et al. ${ }^{8}$ who examined pigs with JE antibody in 12 province in Indonesia (15 regencies) in 2012, namely $14,2 \%$ of pigs with positive JE. However, several previous studies showed higher prevalence than the current study. High rates of infection reported in previous studies were $88-97 \%$ in West Java and Central Java, 94\% in Riau, and $84 \%$ in West Kalimantan. ${ }^{15}$

The prevalence reported in other countries mostly also showed higher rates, for example in Cambodia at $63.5 \%,{ }^{16}$ in Vietnam between 31-79\%, ${ }^{5}$ and in Bangladesh between 16-42\%. ${ }^{17}$ Utilizing the Haemagglutination Inhibition (HI) test, in Thailand the prevalence was found between $0-66.8 \%,{ }^{18}$ in Japan between $0-31.7 \%,{ }^{19}$ in Laos between 87.4$90.2 \%,{ }^{20}$ and even in Vietnam reported all $100 \%$ tested pigs contained JE virus antibodies. ${ }^{5}$ Ompusunggu explained that the difference in prevalence of the infection could be due to many factors including pig population, sample size, age, breeding, examination methods, and time of specimen collection. ${ }^{8}$ Although the prevalence in this study is lower than several previous studies, it still needs to be aware of the potential for JE transmission.

The results of this study indicated that the sex and age of pigs did not correlate with the prevalence of JE in pigs. The prevalence of JE-specific $\mathrm{Ab}$ in pigs aged 4-6 months
(22.7\%) was higher than the prevalence of JE $\mathrm{Ab}$ in 2-3 months old pigs (17.1\%). This result is in line with the results of research in Kapuk, Jakarta, which showed that higher rates of infection is following with increase of age. Correlations between pig age and infection rates are also reported in Cambodia, ${ }^{16}$ Laos, ${ }^{20}$ Vietnam, ${ }^{4}$ and Bangladesh. ${ }^{17}$ This difference results could be due to the difference of age limit when pigs were examined. In this study, the age limit of pigs is between 2 months to $>6$ months, whereas in other studies, they used age limit such as 1-7 months, or even 1.5 years to 3.5 years. The age of pigs could be correlated to the rate of JE infection because by increasing age of pigs, the chances of pigs being bitten by the vector are also higher. In the body of the pigs, immunoglobulin M (IgM $\mathrm{Ab}$ ) is formed within 2-3 days after infection with JE virus and reaches peak after 1 week and subsequently replaced by immunoglobulin $\mathrm{G}$ antibody (Ab IgG). Then, maternal IgG ab to be passed down to the offspring through the milk columns and is able to protect the piglet from JE infection for 3-6 months before the $\mathrm{Ab}$ is lost. Immunoglobulin $\mathrm{G}$ specific to JEV detected in this study, which implied that antibody released because of new infection in pigs $>6$ months. Pigs with new infection could be a potential source of transmission through vectors to other pigs and humans during viremia. Viremia in pigs occurs within 2-5 days after infection and lasts for 2-3 days, or even longer. ${ }^{21}$

The infections in pigs tend to be higher in farms positive for Culex larvae but statistical analysis showed no significant association. Environmental conditions inside and around pig farms in one of the farms in Ngunut District support the existence of larvae of Culex sp. with the presence of several breeding sites. The distance of the breeding area is still within the flight range of Culex mosquitoes. Ciota et al. ${ }^{22}$ notice that Culex mosquitoes flight range is a minimum of $0.16 \mathrm{~km}$ and a maximum of $1.98 \mathrm{~km}$. The Culex sp. has a large role in transmitting the JE virus to pigs because this mosquito is known to prefer 
animals (zoophilic). According to research in Tara-Tara Village and Talikuran Village, North Sulawesi, the availability of habitat and a large area of breeding place affect the number of mosquitoes caught. The abundance of JE infected vector will increase as well as its potential to infect human because of the high pig population. ${ }^{23}$

Our data confirmed that pigs in the area of study were found to be infected with the JE virus. This fact indicated the risk of JE transmission to human, particularly when there is contact between infected pigs and Culex sp. vector. Therefore, vaccination of future breeder pigs in epidemic areas could avoid the occurrence of JE. ${ }^{24}$ In addition, pig farms need to be relocated farther from residential areas that include sparse Culex mosquitoes that become vectors in those locations. The infected pigs may also be the hosts for further spread of JEV by mosquito bites. Therefore, a short distance between dwelling places and piggeries or the habitats of feral pigs will increase the probability of exposure to JEV. Populations living in environments with high mosquito density and surrounded by piggeries are prone to JEV infection. Studies in India show that courtyards of the farmers' households without piggeries, their pigs were all raised in pig farms far away from villages (over 2-5 km). Although large numbers of $C x$. tritaeniorhynchus and $C x$. pipiens pallens were present in the above five courtyards, JEV was not detected from these mosquitoes. ${ }^{25}$ This distance refers to maximum Culex flying ability, so certain distance need to be set to avoid contact with its transmitting mosquitoes Culex. The area of study, pig farms is somewhat separated from the settlements, but the distance is still within the range of the JE vector's flying distance. Since the JE transmission cycle is very complex because it involves several aspects such as land use pattern, pig husbandry, climate change, and human-animal relationship further studies are required for designing more efficient prevention and control strategies.

\section{CONCLUSION}

The presence of JE virus antibodies in pig population in Ngunut and Kalidawir Subdistricts, Tulungagung Regency indicated that there is a potential of transmission of JE virus to humans in case of contact between mosquitoes as vector with the host of the amplifier.

\section{RECOMMENDATION}

Mass vaccination in pigs needs to be done to reduce the number of pigs infected with the JE virus. If the location of the farm is not possible to be moved, it is necessary to eradicate vector around the location of the farm.

\section{ACKNOWLEDGEMENT}

Thank you to the Head of Health Research and Development Center of Banjarnegara Class 1 for the permission and funding. Thanks also to the Head of Livestock Service Office and Head of Health Office and staffs in Tulungagung District for research permission, helping to approach pig farm owners and their assistance in collecting blood specimens of pigs. Also thank to the owner of pigs and inspection technicians in the laboratory for their collaboration and help during the research.

\section{REFERENCES}

1. Saxena SK, Agrawal PT, Nair MPN. Japanese encephalitis: a neglected viral disease and its impact on global health. In: Saxena SK, ed. Trends in Infectious Diseases. IntechOpen; 2014. doi:10.5772/58529.

2. WHO. Japanese encephalitis. https://www.who.int/news-room/factsheets/detail/japanese-encephalitis. Published 2019. Accessed May 22, 2019.

3. Unni S, Růžek D, Chhatbar C, Mishra R, Johri M, Singh S. Japanese encephalitis virus: from genome to infectome. Microbes Infect. 2011;13(4):312-21. doi:10.1016/j.micinf.2011.01.002.

4. Widiarti, Tunjungsari R, Garjito TWA. Pendekatan molekuler konfirmasi vektor Japanese Encephalitis (JE) di Kota Surabaya 
Jawa Timur. Vektora. 2014;6(September):738.

5. Lindahl JF, Ståhl K, Chirico J, Boqvist S, Thu HTV, Magnusson U. Circulation of Japanese Encephalitis virus in pigs and mosquito vectors within Can Tho City, Vietnam. PLoS Negl Trop Dis. 2013;7(4). doi:10.1371/journal.pntd.0002153.

6. Lord J, Gurley E, Pulliam J. Rethinking japanese encephalitis virus transmission: a framework for implicating host and vector species. PLoS Negl Trop Dis. 2015;9:1-7. doi:https://doi.org/10.1371/journal.pntd.00040 74.

7. Garjito TA, Widiarti, Anggraeni YM, Alfiah S, Tunggul Satoto, Farchanny A, et al. Japanese encephalitis in Indonesia: an update on epidemiology and transmission ecology. Acta Trop. 2018;187:240-47. doi:10.1016/j.actatropica.2018.08.017.

8. Ompusunggu S, Maha MS, Dewi RM, Subangkit. Infeksi Japanese Encephalitis pada babi di beberapa provinsi Indonesia tahun 2012. Media Litbangkes. 2015;25(2):1-8.

9. Dinas Peternakan Provinsi Jawa Timur [Internet]. Data Statistik Populasi Ternak Kab/Kota di Jawa Timur. [cited 2019 March 15]. Available from: http://disnak.jatimprov.go.id/web/layananpubl $\mathrm{ik} /$ datastatistik/statistikpopulasiternak.

10. Yamanaka A, Mulyatno KC, Susilowati H, Hendrianto E, Utsumi T, Amin M, et al. Prevalence of antibodies to japanese encephalitis virus among pigs in Bali and East Java, Indonesia, 2008. Jpn J Infect Dis. 2010;63(1):58-60.

11. Detha A, Wuri DA, Santhia K. Seroprevalence of Japanese encephalitis virus using competitive enzyme linked immunosorbent assay (C-ELISA) in pigs in East Sumba, Indonesia. J Adv Vet Anim Res. 2015;2(4):481-3.

doi:10.5455/javar.2015.b112.

12. Cleton N, Bosco-Lauth A, Page M, Bowen R. Age-related susceptibility to Japanese encephalitis virus in domestic ducklings and chicks. Am J Trop Med Hyg. 2014;90:242-6. doi:https://doi.org/10.4269/ajtmh.13-0161.

13. Wolfe ND, Kilbourn AM, Karesh WB, Rahman HA, Bosi EJ, Cropp BC, et al. Sylvatic transmission of arboviruses among
Bornean orangutans. Am J Trop Med Hyg. 2001;64(5-6):310-6.

14. Solomon T, Thao TT, Lewthwaite P, Ooi MH, Kneen R, Dung NM, et al. A cohort study to assess the new WHO Japanese encephalitis surveillance standards. Bull World Heal Organ. 2008;86(3):178-86. doi:10.1590/S0042-96862008000300010.

15. Sendow I, Field HE, Adjid RMA, Lunt R, Ratnawati A, Breed AC, et al. Seroepidemiology of Japanese Encephalitis virus infection in bats and pigs in West Kalimantan, Indonesia. Microbiol Indones. 2008;2(2):79-82

16. Duong V, Sorn S, Holl D, Rani M, Deubel V, Buchy P. Evidence of Japanese encephalitis virus infections in swine populations in 8 provinces of Cambodia: Implications for national Japanese encephalitis vaccination policy. Acta Trop. 2011;120:146-50.

17. Khan SU, Salje H, Hannan A, Islam MA, Bhuyan AAM, Islam MA, et al. Dynamics of Japanese encephalitis virus transmission among pigs in Northwest Bangladesh and the potential impact of pig vaccination. PLoS Negl Trop Dis. 2014;8(9):e3166. doi:10.1371/journal.pntd.0003166.

18. Prompirama P, Taowana N-A, Paungpina, W Poltepa K, Phonarknguena R. Seroprevalence of Japanese encephalitis virus in pigs and wild boar of different part of Thailand. In: Proc 5 Asian Pig Vet Soc Congress; 7-9 March 2011; Pattaya, Thailand; 2011.

19. Nidaira M, Taira K, Okano S, Shinzato T, Morikawa T, Tokumine M, et al. Survey of Japanese encephalitis virus in pigs on Miyako, Ishigaki, Kume and Yonaguni Islands in Okinawa, Japan. Jpn J Infect Dis. 2009;62(3):220-4.

20. Conlan JV, Vongxay K, Jarman RG, Gibbons RV, Lunt RA, Fenwick S, et al. Serologic study of pig-associated viral zoonoses in Laos. Am J Trop Med Hyg. 2012;86(6):1077-84. doi:10.4269/ajtmh.2012.11-0195.

21. Mansfield K, Hernández-Triana, LM Banyard A, Fooks A, Johnson N. Japanese encephalitis virus infection, diagnosis and control in domestic animals. Vet Microbiol. 2017;201:85-92. doi: 10.1016/j.vetmic.2017.01.014.

22. Ciota A, Drummond C, Ruby M, Drobnack J, 
Ebel G, Kramer L. Dispersal of Culex mosquitoes (Diptera: Culicidae) from a wastewater treatment facility. J Med Entomol. 2012;49(1):35-42.

23. Podung A, Pinontoan O, Lumanauw S, Tulung M. Abundance of mosquito species (Diptera: Culicidae) as vector of the Japanese encephalitis disease in the pig sties in north Sulawesi, Indonesia. J Entomol Zool Stud. 2016;4(6):632-7.

24. Ruget AS, Beck C, Gabassi A, Trevenneck K,
Lecollinet S, Chevalier V, et al. Japanese encephalitis circulation pattern in swine of northern Vietnam and consequences for swine's vaccination recommendations. Transbound Emerg Dis. 2018;65(6):1485-92. doi: $10.1111 /$ tbed.12885.

25. Ren X, Fu S, Dai P, Wang H, Li Y, Li X, et al. Pigsties near dwellings as a potential risk factor for the prevalence of Japanese encephalitis virus in adult in Shanxi, China. Infect Dis Poverty. 2017;6(1):100. doi:10.1186/s40249-017-0312-4. 